\title{
Boehmite Sorbs Perrhenate and Pertechnetate
}

\author{
Peng-Chu Zhang", James L. Krumhansl, and Patrick V. Brady \\ MS-0750, Sandia National Laboratories
}

Albuquerque, New Mexico 87185

RECEIVED

AUG $1>2000$

OSTI

Abstract

Boehmite and Al-oxyhydroxide gels sorb $\mathrm{ReO}_{4}{ }^{-}$, a non-radioactive analogue of $\mathrm{TcO}_{4}{ }^{-}$from $\mathrm{NaNO}_{3}$ solutions. Sorption appears to be substantially electrostatic (though there appears to be a specific preference for $\mathrm{ReO}_{4}{ }^{-}$over $\mathrm{NO}_{3}{ }^{\circ}$ ) and is most effective at $\mathrm{pH}<8$. Measured $\mathrm{K}_{\mathrm{d}^{\prime}}$ 's lie between 5 and $105 \mathrm{ml} \mathrm{g}^{-1}$, depending on the solid, $\mathrm{pH}$, and ionic strength. $\mathrm{ReO}_{4}{ }^{-}$and $\mathrm{TcO}_{4}{ }^{-}$are both partially removed from high $\mathrm{pH}$ Hanford-type acid waste simulants upon neutralization and formation of Al-rich sludges. We therefore propose that sequestration of $\mathrm{Tc}$ by boehmite limits dissolved Tc levels in some Hanford tanks, and that boehmite might be relied on as a backfill, or reactive barrier, to limit environmental transport of $T c$.

\footnotetext{
* Corresponding author phone: (505) 844 2669; fax: (505) 844 7354; email: pzhang@sandia.gov
} 


\section{DISCLAIMER}

This report was prepared as an account of work sponsored by an agency of the United States Government. Neither the United States Government nor any agency thereof, nor any of their employees, make any warranty, express or implied, or assumes any legal liability or responsibility for the accuracy, completeness, or usefulness of any information, apparatus, product, or process disclosed, or represents that its use would not infringe privately owned rights. Reference herein to any specific commercial product, process, or service by trade name, trademark, manufacturer, or otherwise does not necessarily constitute or imply its endorsement, recommendation, or favoring by the United States Government or any agency thereof. The views and opinions of authors expressed herein do not necessarily state or reflect those of the United States Government or any agency thereof. 


\section{DISCLAIMER}

Portions of this document may be illegible in electronic image products. Images are produced from the best available original document. 


\section{Introduction}

- Technetium is a common component of nuclear wastes and is of environmental concern because it is generally mobile in groundwaters and has a relatively long half life $\left(2.1 \times 10^{5}\right.$ years). In near surface environments, Tc typically exists in its oxidized form as pertechnetate, $\mathrm{TcO}_{4}^{-}$. Because of its relatively large jonic radii and small negative charge density, $\mathrm{TcO}_{4}^{-}$, negatively charged soil matrices rarely attract and retard $\mathrm{TcO}_{4}{ }^{-}$ (l-3). Moreover, $\mathrm{TCO}_{4}^{-}$forms no insoluble solids (l) that would limits transport in nature.

Recent studies of tank sludges at the Hanford Reservation indicate high levels of solids-associated $\mathrm{Tc}$ (4) suggesting formation of insoluble, or strongly sorbed, Tc. One possibility is that organic components in the tank fluids reduce $\mathrm{TcO}_{4}{ }^{-}$to insoluble $\mathrm{TcO}_{2}$

(2). However, the high nitrate and ferric iron content of the tank fluids point to oxidizing conditions, and instead suggest that some sludge component sorbs $\mathrm{TcO}_{4}^{-}$. Tank sludges are predominantly composed of hydrous oxy-hydroxides of iron and alumininum. Except for inner sphere complexes of $\mathrm{PO}_{4}{ }^{3-}, \mathrm{CrO}_{4}{ }^{2-}, \mathrm{SeO}_{3}{ }^{2-}$, and $\mathrm{AsO}_{4}{ }^{3-}$, iron oxy-hydroxides are not known to sorb anions. Al hydroxides, however, are known to attract anions, though uptake is apparently non-specific and is greatest at pH's less than 9.2 , the point of zero charge in dilute fluids (5). Anions sorb to aluminum hydroxide gels in roughly the order: phosphate $>$ carbonate $>$ sulfate $>$ chloride $=$ nitrate (6-9).

We hypothesize that aluminum oxyhydroxide and boehmite $[\mathrm{AlO}(\mathrm{OH})]$ removed pertechnetate from the waste storage tank solutions. We confirm this by measuring 
adsorption of $\mathrm{ReO}_{4}{ }^{\circ}$, a non-radioactive analogue for $\mathrm{TcO}_{4}{ }^{\circ}$ (possessing similar charge, radius and structure), on well crystalline boehmite or an amorphous aluminum oxyhydroxide. Subsequent confirmation of appreciable uptake was made with $\mathrm{TcO}_{4}{ }^{-}$. We therefore propose that aluminum hydroxides in general, and boehmite in particular, should be considered as reactive components of engineered chemical backfills and reactive barriers designed to limit the transport of pertechnetate into the environment.

\section{Materials and Methods}

Pertechnetate adsorption on aluminum hydroxides was measured on two phases: a well crystalline boehmite $[\mathrm{AlO}(\mathrm{OH})]$ and an aluminum gel. Boehmite was prepared by heating a commercial aluminum hydroxide $\left[\mathrm{Al}(\mathrm{OH})_{3} \cdot \mathrm{nH}_{2} \mathrm{O}\right]$ (Fisher Scientific), which has a typical gibbsite structure as demonstrated by its XRD pattern (Figure 1a), in an oven at $240^{\circ} \mathrm{C}$ for 24 hours. The only mineral identified by XRD from the heated aluminum hydroxide (which lost about $20 \%$ of its original weight from water during the period of heating) was a well crystallized boehmite as shown by the characteristic peaks (Figure 1b). Before use the mineral was passed through a 200 mesh (pore diameter $=$ $0.043 \mathrm{~mm}$ ) sieve.

Aluminum gel was prepared by titrating a $1.0 \mathrm{~N} \mathrm{NaOH}$ solution into a $0.1 \mathrm{~N}$ $\mathrm{Al}\left(\mathrm{NO}_{3}\right)_{3}$ solution to $\mathrm{pH} 9$ under vigorous stirring. After the $\mathrm{pH}$ stabilized, the suspension was aged in an incubator at $90^{\circ} \mathrm{C}$ for two days. The $\mathrm{pH}$ of the suspension was periodically checked and adjusted as necessary during incubation. The suspension was subsequently dialyzed in a dialysis tube in a deionized water bath. The water was 
changed daily until the dialysis solution was free of $\mathrm{NO}_{3}{ }^{-}$as measured by a nitrate test strip.

A $0.001 \mathrm{~mol} \mathrm{~L}^{-1} \mathrm{ReO}_{4}{ }^{-}$stock solution was prepared by dissolving $0.289 \mathrm{~g}$ of $\mathrm{KReO}_{4}$ in $1.00 \mathrm{~L}$ of deionized water. Re in solution was measured using a directly coupled plasma spectrophotometer (DCP). Rhenium DCP standards were prepared from dilution of $1010 \mathrm{mg} \mathrm{L}^{-1}$ standard atomic absorption Re solution (Fisher Scientific).

\section{Methods:}

\section{Adsorption on Boehmite}

a. Effect of $p H$ on adsorption

One liter $(1.00 \mathrm{~L})$ of boehmite suspension, with a solid concentration of $30.0 \mathrm{~g} \mathrm{~L}$ '

${ }^{1}$, was made by combining $0.50 \mathrm{~L}$ of the Re stock solution $\left(0.001 \mathrm{~mol} \mathrm{Re}^{-1}\right), 0.50 \mathrm{~L}$ of $0.001 \mathrm{~N} \mathrm{NaNO}_{3}$ solution, and $30.0 \mathrm{~g}$ of boehmite. The suspension was stirred with a magnetic bar while the $\mathrm{pH}$ was adjusted with a $0.1 \mathrm{~N} \mathrm{HNO}_{3}$ solution. The $\mathrm{pH}$ range tested in this study was 5.0 to 9.6 . When the desired $\mathrm{pH}$ was obtained, two $20.0 \mathrm{ml}$ of suspension were taken and placed into two $40 \mathrm{ml}$ covered polyethene bottles. The suspensions in the bottles were then agitated on a shaker at the rate of $100 \mathrm{rpm}$ for 18 hours. The $\mathrm{pH}$ in each suspension was measured after shaking. The final $\mathrm{pH}$ 's generally shifted less than 0.5 units from the starting $\mathrm{pH}$. The solids from the suspension were then separated using a $0.1 \mu \mathrm{m}$ membrane and syringe apparatus. Filtrates were analyzed for Re and the amount of Re removed is calculated from the difference between initial Re concentration, $5 \times 10^{-4} \mathrm{~mol} \mathrm{~L}^{-1}$, and the concentration in the filtrate. 


\section{b. Effect of ionic strength on adsorption}

In a parallel series of tests, the ionic strength was adjusted with a $1.0 \mathrm{~N} \mathrm{NaNO}_{3}$ solution to $0.0005,0.001,0.005,0.05$ and $0.10 \mathrm{M}$. The initial $\mathrm{pH}$ was adjusted at 5.8 for all tested samples and the final $\mathrm{pH}$ values almost uniformly shifted to the range of 6.2 6.4. The $\mathrm{ReO}_{4}^{-}$concentration was $5 \times 10^{-4} \mathrm{~mol} \mathrm{~L}^{-1}$. Duplicates were run and $\mathrm{Re}$ uptake determined as described above.

c. Effect of solid/iquid ratios on adsorption

Boehmite concentrations of $1.0,5.0,15.0,30.0$ and $60.0 \mathrm{~g} \mathrm{~L}^{-1}$ were used and Re uptake measured from a $5 \times 10^{-4} \mathrm{~mol} \mathrm{~L}^{-1}$ Re solution. The ionic strength was $1 \times 10^{-3}$ $\mathrm{M}$ and the $\mathrm{pH}$ was in the range of 5.7 (initial) to 6.0 (final).

\section{2. $\mathrm{ReO}_{4}{ }^{-}$Adsorption on Aluminum Gel}

An aliquot of dialyzed aluminum gel was pipetted into a $25 \mathrm{ml}$ polyethene bottle containing a $0.001 \mathrm{M} \mathrm{KReO}_{4}$ solution. Suspension $\mathrm{pHs}$ were adjusted with $0.1 \mathrm{~N} \mathrm{HNO}_{3}$ and $0.1 \mathrm{~N} \mathrm{NaOH}$ solutions. After $18 \mathrm{~h}$ shaking, the suspensions were centrifuged and the liquid phase passed through a $0.1 \mu \mathrm{m}$ membrane. For some suspensions, the ultrafiltration membrane cones (Micon) were used to separate solid and liquid under centrifugation. The solid concentration was determined from the dry weight of $10 \mathrm{ml}$ of the aluminum gel.

\section{Results and Discussion}

I. Adsorption of $\mathrm{ReO}_{4}$ i on Boehmite Surface 
Adsorption of $\mathrm{ReO}_{4}{ }^{-}$on boehmite is $\mathrm{pH}$ dependent and decreases with increasing $\mathrm{pH}$ (See figure 2). Approximately $80 \%$ and of the added $\mathrm{ReO}_{4}^{-}\left(5 \times 10^{-4} \mathrm{~mol} \mathrm{~L}^{-1}\right.$, or 93 $\mathrm{mg} \mathrm{Re} \mathrm{L}^{-1}$ ) was removed from the liquid phase at $\mathrm{pH}$ 5.4. Adsorption of $\mathrm{ReO}_{4}^{-}$ gradually decreases with $\mathrm{pH}$ and at $\mathrm{pH} 9$, adsorption is minimal. Although the point of zero charge (PZC) of boehmite was not measured, the PZC of boehmite and pseduboehmite has been reported to be about $8.7-9.2(10)$. The $\mathrm{ReO}_{4}{ }^{-}$adsorption isotherm observed in this study is broadly consistent with previously observed anion uptake reported in literature.

The distribution coefficient $\left(\mathrm{K}_{\mathrm{d}}, \mathrm{ml} \mathrm{g}^{-1}\right)$, which is widely applied in models for contaminant transport in subsurface, is the ratio of concentrations of solute sorbed on the surface and in the liquid phase and can be calculated from:

$$
K_{d}=\left(C_{i n i}-C_{e q}\right) V /\left(S C_{e q}\right)
$$

where $\mathrm{C}_{\text {ini }}$ is the initial $\mathrm{ReO}_{4}{ }^{-}$concentration, $\mathrm{C}_{\mathrm{eq}}$ is the $\mathrm{ReO}_{4}{ }^{-}$concentration at equilibrium, $\mathrm{V}$ is the volume of suspension (ml) and $\mathrm{S}$ is the amount of boehmite solid in the suspension $(\mathrm{g})$. Measured $\mathrm{K}_{\mathrm{d}}$ values are plotted in Figure 3. The high $\mathrm{K}_{\mathrm{d}}$ values at the slightly acidic and neutral $\mathrm{pH}$ conditions indicate a high capacity of boehmite to retard $\mathrm{ReO}_{4}^{-}$. On the basis of electrostatic considerations, one might also expect even greater pertechnetate uptake under the same conditions since $\mathrm{TcO}_{4}{ }^{*}$ has a slightly smaller ionic radii and higher charge density which should allow more ready access to the positively charged boehmite surface.

Nitrate ion competition with $\mathrm{ReO}_{4}{ }^{-}$is significant, and is shown in Figure 4a. Under identical initial $\mathrm{ReO}_{4}{ }^{-}$concentration $\left(5 \times 10^{-4} \mathrm{~mol} \mathrm{~L}^{-1}\right)$, solid concentration $(30 \mathrm{~g}$ $\left.\mathrm{L}^{-1}\right)$, and $\mathrm{pH}-6.2( \pm 0.2)$, the amount of $\mathrm{ReO}_{4}^{-}$adsorbed on boehmite decreases from 
$8.10( \pm 0.25)$ to $2.22( \pm 0.18) \mu \mathrm{mol} \mathrm{g}-1$ when $\left[\mathrm{NO}_{3}^{-}\right]$changes from $1.00 \times 10^{-3}$ to $0.1 \mathrm{~mol}$ $\mathrm{L}^{-1}$. Correspondingly, the $\mathrm{K}_{\mathrm{d}}$ decreases from $31.64( \pm 1.97)$ to $5.13( \pm 0.47) \mathrm{ml} \mathrm{g}^{-1}$. Although $\mathrm{NO}_{3}{ }^{-}$competition measurably decreases $\mathrm{ReO}_{4}{ }^{-}$adsorption, the competition is not stoichiometric (See figure 4b). Instead, $\mathrm{ReO}_{4}{ }^{-}$uptake is preferred. Note that a 2 order of magnitude increase in nitrate levels causes less, than a factor of 7 decrease in $\operatorname{Re}$ $\mathrm{K}_{\mathrm{d}}$ 's (Adsorption of $\mathrm{NO}_{3}{ }^{-}$was not actually measured, partially because a $\mathrm{HNO}_{3}$ solution was used to adjust $\mathrm{pH}$ ).

Increasing the boehmite to solution ratio increases the amount of $\mathrm{ReO}_{4}{ }^{-}$sorbed (see Figure $5 \mathrm{a}$ ). $\mathrm{ReO}_{4}{ }^{-}$adsorption, calculated on a per gram of boehmite basis, actually decreases though. One explanation may be that the maximum adsorption capacity of the boehmite was not reached in the experiments. This conclusion can be drawn indirectly from Figure $5 \mathrm{~b}$ which shows that $\mathrm{K}_{d}$ 's decrease with increasing solid/liquid ratio. In the low solid concentration system, there is less likelihood of solid particle aggregation, and there is more opportunity for aggregated solids to separate. Therefore, the surface area per unit weight of boehmite exposed to the solution is likely to be larger at low solids concentration, which would enhance $\mathrm{ReO}_{4}{ }^{-}$adsorption. The opposite effect is expected in the higher solid system. In fact, $\mathrm{K}_{d}$ 's are not that sensitive to the solid/liquid ratio when the solid concentration is equivalent to, or higher than, $15 \mathrm{~g} \mathrm{~L}^{-1}$.

\section{Sorption of $\mathrm{ReO}_{4}{ }^{-}$on Aluminum Oxyhydroxide $\mathrm{Gel}$}

From our measurements it is impossible to unambiguously identify a $\mathrm{ReO}_{4}{ }^{-}$ sorption mechanism for Al-O gels. The Al-O gel did not have distinguishable particle characteristics; tended to dissolve at $\mathrm{pH}<5$; formed a new phase at $\mathrm{pH}>8$; and was 
almost impossible to separate from solution by filtration (instead high speed centrifugation was used). Because of the accumulated experimental uncertainties, we will only discuss sorption in a semi-quantitative fashion without attributing the sorption to any specific mechanism. Table 1 gives $\mathrm{ReO}_{4}^{-} \mathrm{K}_{\mathrm{d}}$ 's for $\mathrm{Al}-\mathrm{O}$ gels.

Table 1. Sorption of $\mathrm{ReO}_{4}$ - on the Aluminum Oxyhydroxide $\mathrm{Gel}, \mathrm{pH}=7.1-7.3$, background electrolyte $\mathrm{NaNO}_{3}=0.001 \mathrm{~mol} \mathrm{~L}^{-1}$.

\begin{tabular}{ccccc}
\hline Solid/Liquid & $\begin{array}{c}\text { Re sorbed } \\
\left(\mathrm{mg} \mathrm{g}^{-1}\right)\end{array}$ & Total Volume (ml) & $\begin{array}{c}\text { Final Re Conc. } \\
\left(\mathrm{mg} \mathrm{L}^{-1}\right)\end{array}$ & $\begin{array}{c}\mathrm{K}_{\mathrm{d}} \\
\left(\mathrm{mL} \mathrm{g}^{-1}\right)\end{array}$ \\
\hline $2 / 150$ & 0.51 & 15 & 20.3 & 23.6 \\
$2 / 150$ & 0.44 & 15 & 20.9 & 20.8 \\
$1 / 100$ & 0.71 & 10 & 32.9 & 21.9 \\
$1 / 100$ & 0.74 & 10 & 32.6 & 22.7 \\
$1 / 500$ & 1.45 & 50 & 13.1 & 110.7 \\
$1 / 500$ & 1.40 & 50 & 13.2 & 106.1 \\
\hline
\end{tabular}

III. Application to Tank Sludges

The Re uptake results outlined above strongly suggest that sorption onto Al-oxyhydroxides may be one cause for the high Tc content of Hanford tank sludges. They also point to reliance on $\mathrm{Al}$-oxyhydroxides as a potential method for immobilizing $\mathrm{Tc}$ in natural groundwater systems. To further test the tank immobilization hypothesis, five synthetic tank sludges were made by neutralizing the five Hanford-type simulant acidic reprocessing fluids (4). Prior to neutralization the fluids were individually doped with 
$\mathrm{ReO}_{4}{ }^{-}(40.0 \mathrm{ppm} \mathrm{Re}), \mathrm{TcO}_{4}{ }^{-}(1.0 \mathrm{ppm} \mathrm{Tc})$ and $\mathrm{SeO}_{4}{ }^{2-}(40.0 \mathrm{ppm} \mathrm{Se})$. Because $\mathrm{Al}$ and $\mathrm{Fe}$ are the principal sludge components the recipes are tabulated as molar ratios in Table 2 (although the high $\mathrm{pH}$ dictates that an appreciable fraction fo the $\mathrm{Al}$ remained in the solution).

(Insert Table 2 here)

Two things are immediately evident from Table 2 , the most important being that $\mathrm{TcO}_{4}^{-}$behavior mirrors, at least semiquantitatively, that of $\mathrm{ReO}_{4}^{-}$. It is also evident that significant anion removal only occurrs in the synthetic sludges rich in aluminum. X-ray diffraction confirmed that boehmite was the principal component of the high $\mathrm{pH}$ aluminum sludges.

From the $\mathrm{ReO}_{4}^{-}$results described earlier one might also infer that both the high $\mathrm{pH}$ and nitrate content of the fluids would preclude retaining sorbed anions in the final fluids. However, the Al-oxy-hydroxide precipitates formed as the solutions changed from being mildly acidic to slighty basic. In this $\mathrm{pH}$ range there is a significant potential for anion sorption and subsequent occlusion. We hypothesize that $\mathrm{SeO}_{4}{ }^{2-}, \mathrm{ReO}_{4}{ }^{\circ}$ and $\mathrm{TcO}_{4}{ }^{-}$sorbed onto freshly formed surfaces at this time and were occluded by further $\mathrm{Al}$ $\mathrm{O}-\mathrm{OH}$ precipitation, and thus prevented from subsequently desorbing into high $\mathrm{pH}$ solutions. 


\section{Acknowledgements}

We greatly appreciate financial support of the Environmental Management Science

Program and the Sandia National Laboratories - LDRD Office.

\section{Literature Cited}

1. Gu, B.; Schulz, R. K. "Anion retention in soil: Possible application to reduce migration of buried technetium and iodine," U.S. Nuclear Regulatory Commission, NUREG/CR-5464, 1991.

2. Kaplan, D. I.; Serne, R. J. "Distribution coefficient values describing Iodine, Neptunium, Selenium, Technetium, and Uranium sorption to Hanford Sediments," Pacific Northwest Laboratory, PNL-10379, SUP.1, 1995.

3. Rai, D.; Zachara, J. M. "Chemical attenuation rates, coefficients, and constants in leachate migration," Electric Power Research Institute, EPRIEA-3356, 1984.

4. Field, J. G.; Lance, C. A. "Tank characterization report for single-shell tank 241-AX104," Lockheed Martin Hanford Corp., HNF-SD-WM-ER-675, 1999.

5. Wood, R.; Fornasiero, D.; Ralston, J. Colloids Surf. 1990, 37, 389-395.

6. Lei, J. C. Vaccine 1985, 3, 154-155.

7. Beyrouty, C. A.; Vanscoyoc, G. E.; Feldkamp, J. R. Soil Science Society of America Joumal 1984, 48, 284-287.

8. Eisenreich, S. J.; Armstrong, D. E. Journal of Environmental Science and Health Part a-Environmental Science and Engineering 1978, 13, 337-364.

9. Lewisruss, A. Advances in Agronomy 1991, 46, 199-243.

10. Tanaka, S.; Nagai, H.; Kato, A. Nippon Kagaku Kaishi 1991, 1303-1305. 
Table 2. Sequestration of Tc by Simulated Hanford Tank Sludge

\begin{tabular}{|c|c|c|c|c|c|c|c|c|c|}
\hline Waste & $\mathrm{Al} /(\mathrm{Al}+\mathrm{Fe})$ & $\mathrm{Fe} /(\mathrm{Al}+\mathrm{Fe})$ & $\mathrm{Zr} /(\mathrm{Al}+\mathrm{Fe})$ & $\mathrm{Bi} /(\mathrm{Al}+\mathrm{Fe})$ & $\mathrm{Cr} /(\mathrm{Al}+\mathrm{Fe})$ & $\mathrm{Ni} /(\mathrm{Al}+\mathrm{Fe})$ & $\% \mathrm{Re}$ & $\% \mathrm{Tc}$ & $\% \mathrm{Se}$ \\
\hline Stream & & & & & & & Sorbed & Sorbed & Sorbed \\
\hline Bi-phosphate & 0.72 & 0.28 & $2.6 \times 10^{-3}$ & 0.1 & $2.7 \times 10^{-2}$ & $1.4 \times 10^{-2}$ & 0 & 0 & 0 \\
\hline U-recovery & 0 & 1.0 & 0 & 0 & $7.0 \times 10^{-2}$ & $3.5 \times 10^{-2}$ & 0 & 0 & 0 \\
\hline REDOX & 0.96 & 0.04 & 0 & 0 & $6.1 \times 10^{-2}$ & $3.5 \times 10^{-2}$ & 20 & 33 & 29 \\
\hline Purex-Al clad & 0.87 & 0.13 & $3.3 \times 10^{-3}$ & 0 & $8.7 \times 10^{-2}$ & $1.1 \times 10^{-2}$ & 40 & 28 & 35 \\
\hline Purex-Zr clad & 0 & 1.0 & 2.5 & 0 & $8.5 \times 10^{-2}$ & $3.7 \times 10^{-2}$ & 0 & 0 & 0 \\
\hline
\end{tabular}




\section{Title of Figures}

Figure 1. XRD patterns for: a. Aluminum hydroxide or gibbsite; b. Boehmite $[\mathrm{AlO}(\mathrm{OH})]$; and $c$. Synthetic aluminum oxyhydroxide gel. The aluminum oxyhydroxide gel has a structure of poorly crystallized boehmite.

Figure 2. Removal of perrhenate by boehmite under various $\mathrm{pH}$ 's.

Figure 3. Distribution coefficient $\left(\mathrm{K}_{\mathrm{d}}\right)$ of perrhenate in the boehmite suspension as a function of $\mathrm{pH}$.

Figure 4. Effect of $\mathrm{NO}_{3}{ }^{-}$(as a competing anion) concentration on removal of perrhenate by boehmite (a) and $\mathrm{K}_{d}(\mathrm{~b})$.

Figure 5. Effect of boehmite solid concentration on removal of perrhenate (a) and $\mathrm{Kd}$ (b). 

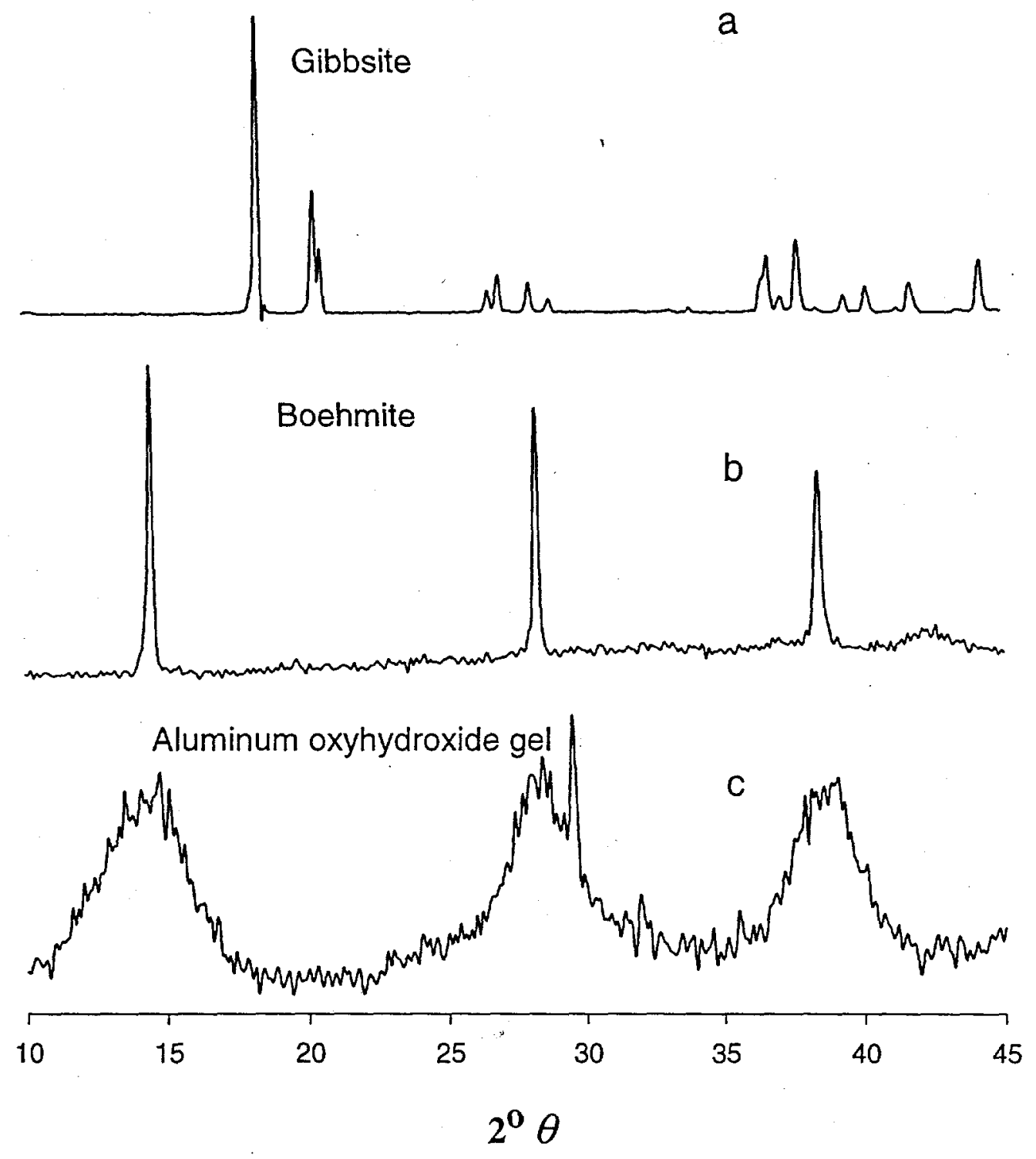

fyore 1 


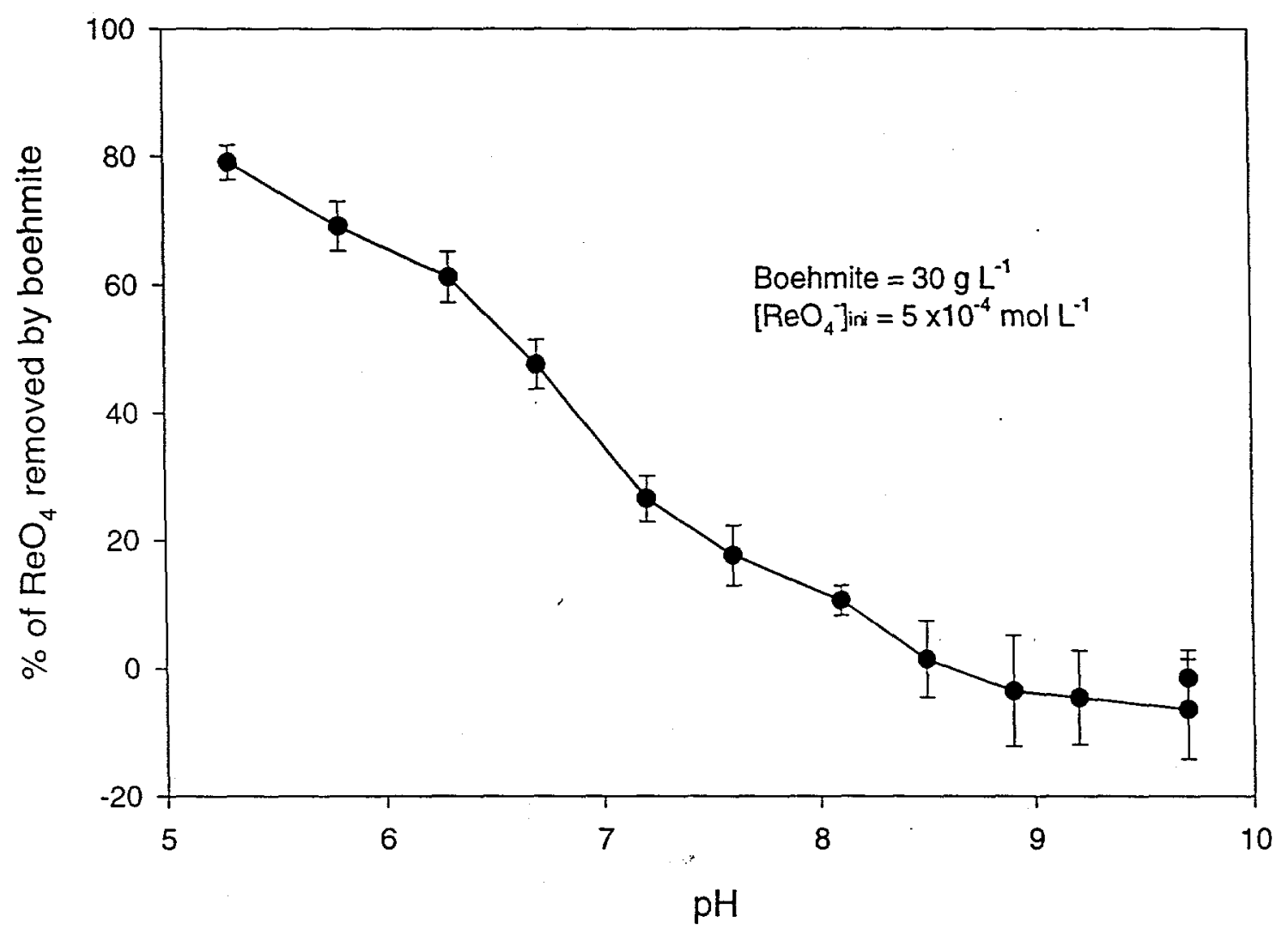

Fipure 2 


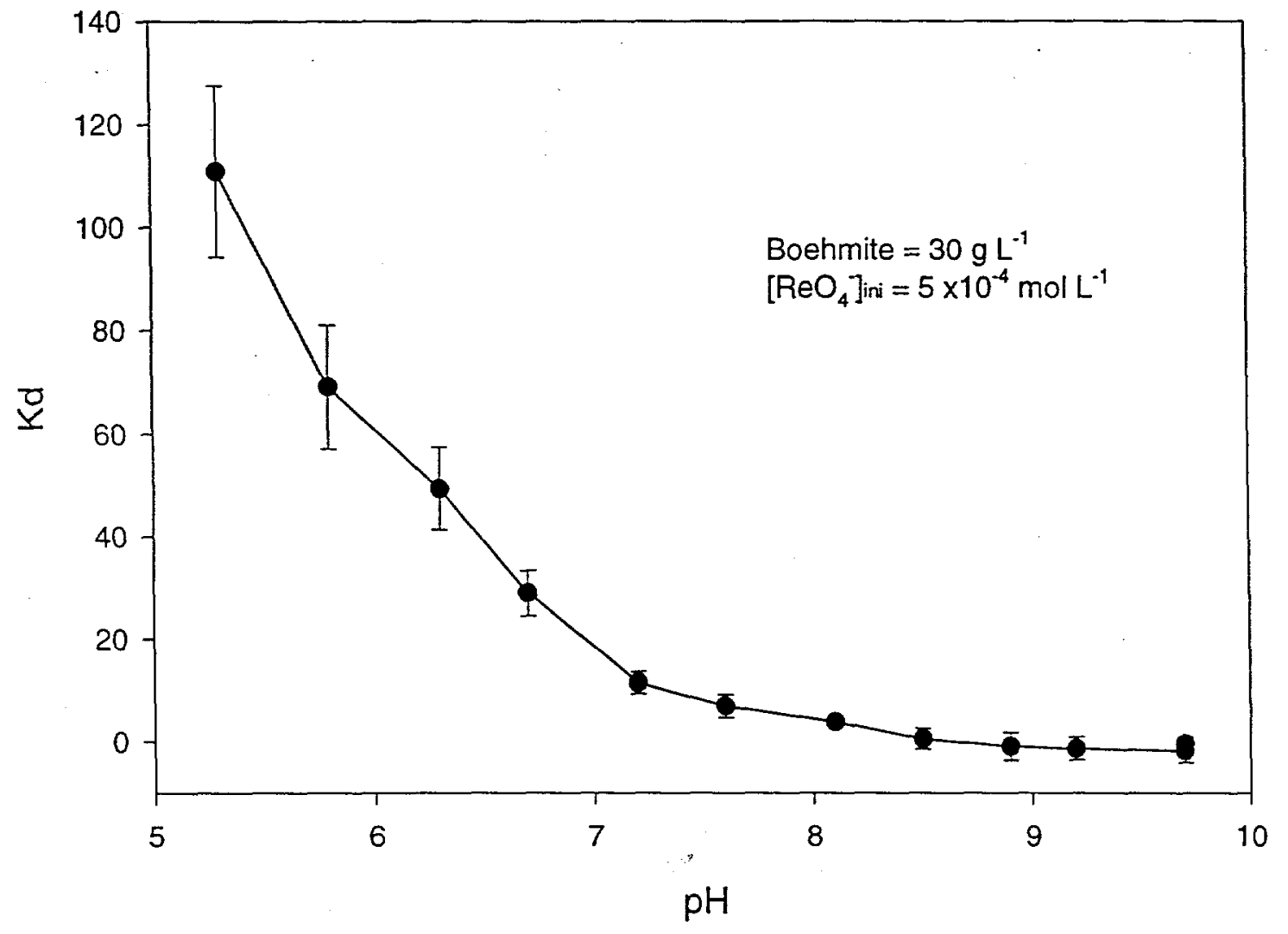

Fignere 3 

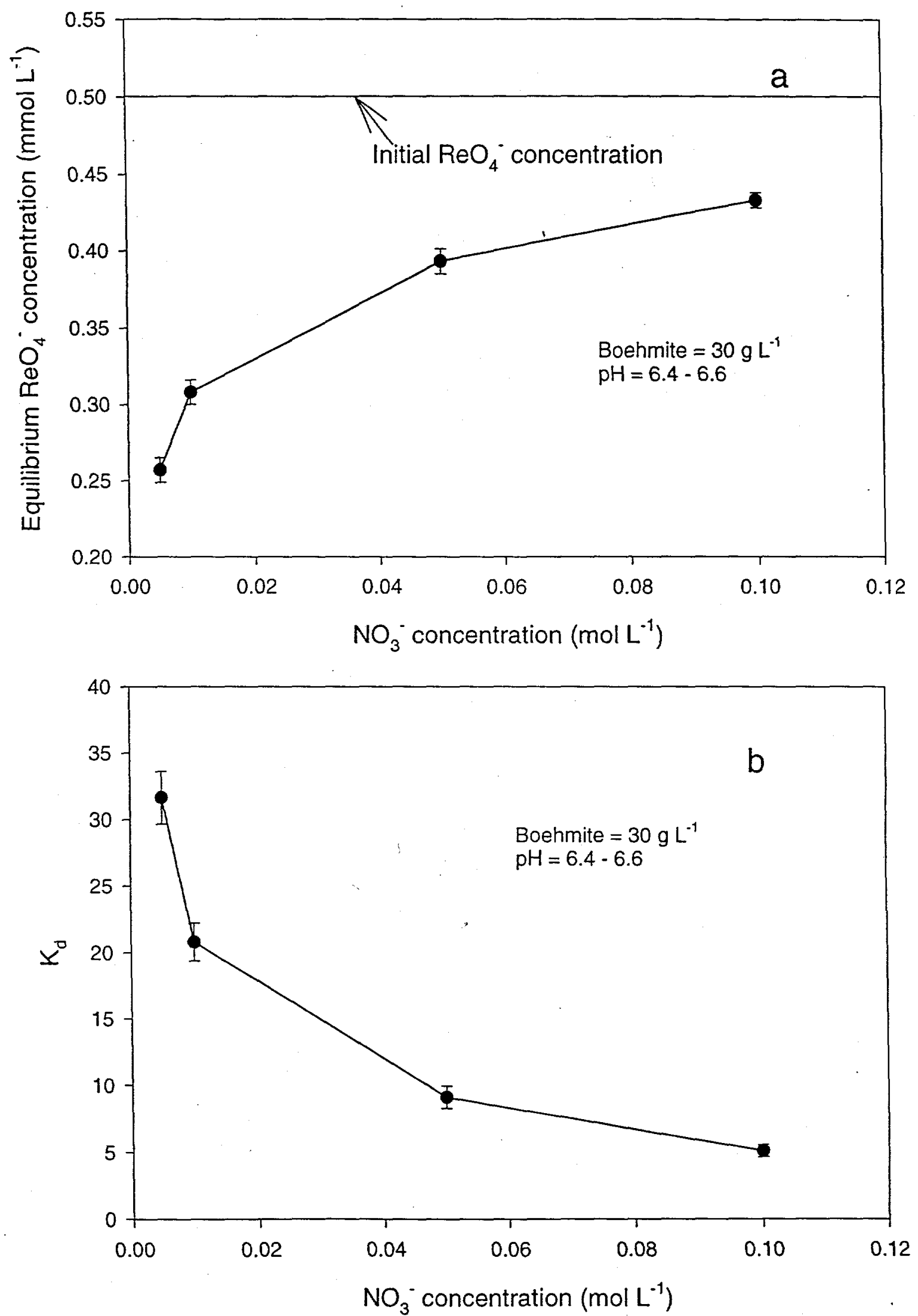

figur 4 

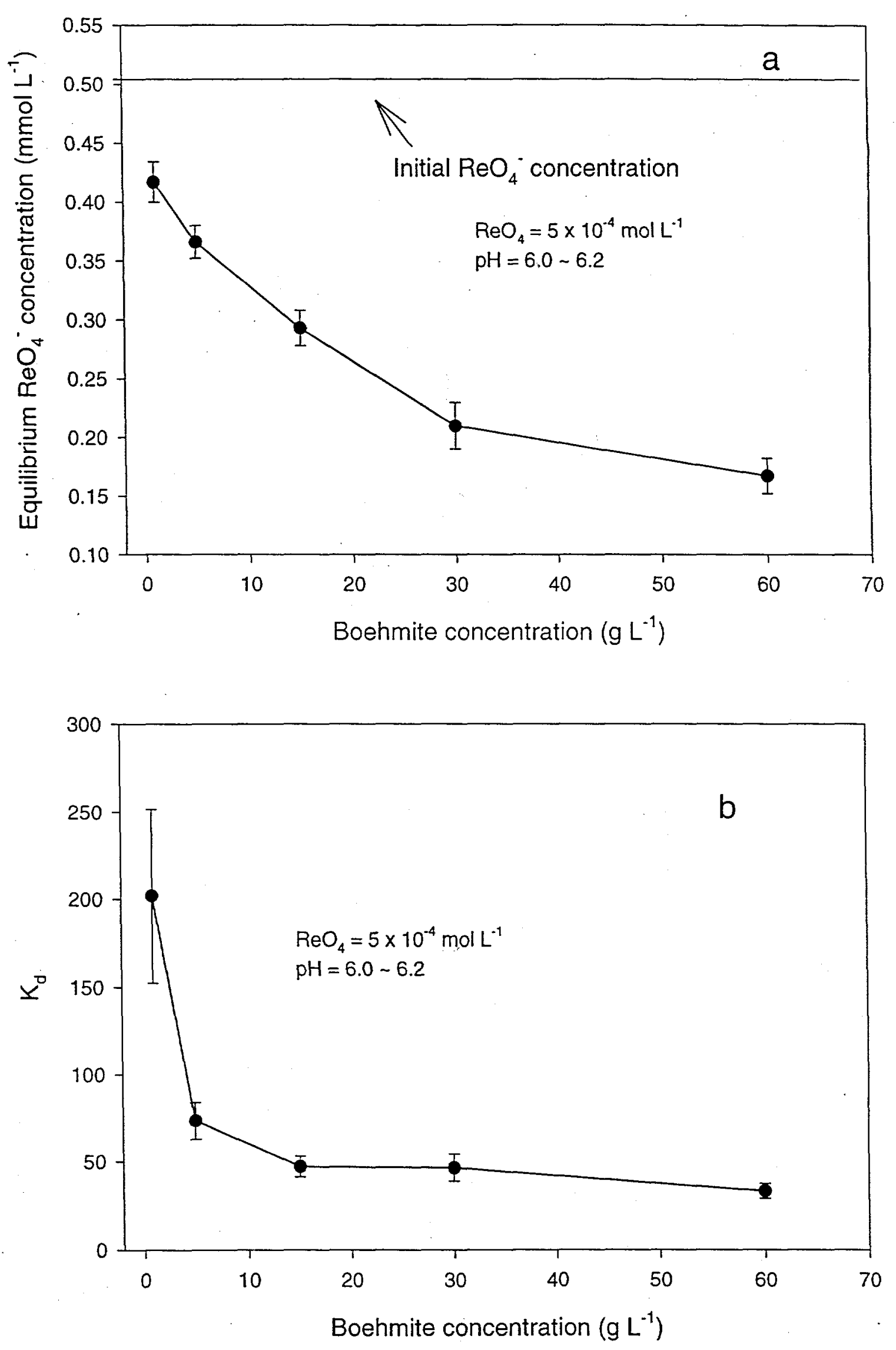

Tiguen 5 